\title{
Housing rehabilitation and reconstruction in Central Sulawesi post-2018 earthquake
}

\author{
Nur Hidayah*, Iman Satyarno, and Ashar Saputra \\ Department of Civil and Environmental Engineering, Gadjah Mada University, Yogyakarta, Indonesia
}

\begin{abstract}
The 2018 Palu Earthquake had damaged many community houses. The post-earthquake settlements program is the construction of temporary shelter and permanent house. The paper discusses to evaluate the development and propose rehabilitation and reconstruction applied in Central Sulawesi. All data were obtained by questionnaire, interviews, and field observations. The data is analyzed in a result framework for the shelter evaluation and a comparison to other post-earthquake programs for permanent house development. The research found the temporary shelter is occupied by only $52 \%$ because of impractical mobilization, living cost assistance absence, uncomfortable conditions, lack of clean water, and several refugees have reconstructed their houses. A low satisfaction rate is caused by the inadequate indoor condition, small capacity, and lack of privacy. This rate makes the temporary shelter is less effective. Regarding the permanent house development, the construction of relocated and satellite houses use modular houses, while the house reconstruction program authorizes the community to choose the preferred house model. The result is concerned to be different in occupancy and satisfaction level, in which the house reconstruction program will be more accepted. Since the temporary shelter and permanent house development requires relocated sites, land provision has slowed down the pre-construction stage.
\end{abstract}

Keywords: proposed methods, occupancy rate, satisfaction rate, relocated house, house reconstruction

\section{Introduction}

The Sendai Framework for Disaster Risk Reduction 2015-2030 is an instrument of disaster risk management that emphasizes the understanding of hazard risk, vulnerability, and calamity characteristics, strengthening disaster risk governance and investing in disaster risk minimization. Valuable lessons from prior disasters urge the need to enhance responses on effective post-disaster handling and upcoming disaster preparedness. An efficient recovery process must follow the requirements above and implement the Build Back Better principle to ensure national and community disaster resilience [1].

The 2018 Palu Earthquake was one of the destructive disasters that caused many fatalities in Indonesia. The earthquake-induced secondary disasters such as tsunami and liquefaction which affect many areas to become red zones that should not be inhabited by the community. The post-disaster settlement management programs adapt not only earthquake-resistant provisions but also the other disasters. It is why the post-earthquake settlement management program in Central Sulawesi is interesting to be discussed, while the rehabilitation and reconstruction program is still ongoing.

The Central Sulawesi rehabilitation and reconstruction program is started in April 2019 until 2021 with the focus on settlement, infrastructure, economy, socio-cultural, and cross-sector development. The project is enacted in Governor of Central Sulawesi Regulation No. 10 of 2019 on Post-Disaster Rehabilitation and Reconstruction Plan. Every executed recovery program is based on three strategies, which are achieving risk reduction within the sustainable development framework in all levels, diminishing the vulnerability level by the quality of life improvement, and escalating the capacity of the government and community in disaster management. Those strategies are accomplished by using the basic principle of Build Back Better, which is implemented in the disaster risk reduction plan and community disaster resilience improvement [2].

Post-disaster housing rehabilitation is carried out by developing temporary shelters and permanent houses. The construction of temporary shelters was executed based on Indonesia Presidential Instruction No. 10 of 2018 and Indonesia National Disaster Management Authority Regulation No. 7 of 2008. The regulations mandate that temporary shelter is used for disaster refugees in mass, family, or individual forms. The shelters may be provided in tents, barracks, or public/ social facilities such as worship places, sports buildings, community halls, and so on [3], [4]. The Government built temporary shelters to accommodate the daily activities of people whose houses were severely damaged by the disaster.

\footnotetext{
* Corresponding author: nurhidayah87@mail.ugm.ac.id
} 
The following housing program is the development of permanent houses by adopting an earthquakeresistant housing method. The construction sites are in the low disaster-prone zones/ ex-site areas and in-site areas. Relocated houses are intended for the refugees who had damaged houses and had lived in the red zone. In contrast, house reconstructions are provided for other damaged house owners in the original/ in-site locations. The Government completes the relocated housing program with supporting infrastructures for settlements [2].

From the issues above, this research aims to evaluate the temporary shelter development program and utilization, evaluate the permanent house development programs, and formulate a better settlement recovery method in Central Sulawesi.

\section{Post-Disaster Rehabilitation and Reconstruction Programs in Indonesia}

\subsection{The temporary shelter program in Yogyakarta post-2010 Merapi eruption}

The eruption had displaced approximately 350,000 people, and 2,682 households lost their houses. A permanent house recovery program could not be directly implemented, which caused the temporary shelter is needed to restore the community's life. The program was started in November 2010 - April 2011 [5].

The temporary shelter program was not only developing shelters, but also equipped with supporting facilities and infrastructure for instance roads, drainage system, clean water supply, sanitary facilities, community meeting hall, mosque, school, market, cattle cage, fish pond, and electrical facilities [6]. Since the occupancy of temporary shelter for $1-2$ years, the shelters were designed as individual shelters, not barracks or communal shelters to provide more privacy for occupants. Every household was entitled to one 36 $\mathrm{m}^{2}$ unit. The occupancy process was started when the construction was completed. The occupants from the same village were relocated to the same temporary shelter location simultaneously. Community routine activities smoothly ran as usual [5].

\subsection{Rehabilitation and reconstruction program using an agency-driven reconstruction by using the contractor in Aceh post-2004 earthquake}

The rehabilitation and reconstruction program was executed by Badan Rehabilitasi dan Rekonstruksi (BRR) or the Aceh-Nias Rehabilitation and Reconstruction Agency to restore infrastructure, livelihoods, social life, and public services. Due to the urgency of the Government to produce entire 139,195 houses in target and sufficient funding from donors, the Government hired contractors. This agency-driven reconstruction approach by using the contractors was considered adequate to meet the program deadline and empower local contractors. This top-down approach was also chosen because it can show the development results, which can be faster completed and meet the earthquake-resistant standards. Its construction brought in materials from outside and experienced craftsmen to control the development speed and reduce the risk of inappropriate material and craftsmen. There was no community involvement, which they only need to receive the results of house reconstruction.

Nevertheless, the housing development program had delivered several problems as below [7]:

1. Bidding for 1,000 contractors in a short time induced a limited quality and capacity of the selected contractors;

2. The inadequate ability of many contractors led to unfinished and delayed construction;

3. Misuse of donor funds $(10-15 \%$ of deduction for personal profit) had prompted the contractors to diminish the material quality and hire unskilled craftsmen; and

4. Local people demanded involvement as the carpenters even though they have a lack of capacity.

\subsection{Rehabilitation and reconstruction program using a community-based approach in Yogyakarta post-2006 earthquake}

The rehabilitation and reconstruction program, well known as Rekompak, was pioneered by the Java Reconstruction Fund (JRF). The programs aimed to empower local communities in efforts to reconstruct houses, restore public infrastructure, and revitalize socio-economic life. The fundamental character of caring and cooperated tradition or gotong royong were appropriately combined with the Rekompak method [8].

Since the beginning of the programs, the community had involved in every decision-making process, such as the development planning phase and house reconstruction stage. In the planning phase, communities were requested to prioritize the most help needed members, set up the house design, choose the necessary public infrastructure, and enact the maintenance plans. In the reconstruction stage, communities fully supervised the physical progress, and transparently inspected the cash flow. Settlement reconstruction with this approach produced the house owner's high satisfaction rate and accomplishment of nearly 200,000 dwellings in less than two years. This achievement is one of the best examples of the biggest and fastest settlement reconstruction [8].

\subsection{Rehabilitation and Reconstruction Program using the modularl off-site construction in Lombok post-2018 earthquake}

Innovations of the earthquake-resistant house have been applied since the rehabilitation and reconstruction program in Lombok. This off-site construction approach is an alternative to the on-site or conventional 
construction method, which are generally the current building construction methods. The off-site construction refers to the manufacturing process of elements, components, or building modules prior to installation at the construction site [9]. These innovations are named as Steel Structure Instant House or Rumah Instan Struktur Baja (Risba) and Healthy Simple Instant House or Rumah Instan Sederhana Sehat (Risha). Gadjah Mada University recommended Risba, and Risha was introduced by the Settlement Research and Development Centre of Ministry of Public Works and Housing as several alternatives for earthquake-resistant community houses.

Risba can be prioritized as a house reconstruction method on the original house that has been damaged by an earthquake. A lightweight Risba does not require a foundation such as a heavy building structure [10]. Risha is a compact and modular house technology which using a fabricated knock-down precast concrete [11]. The Risha approach is worthwhile if it is constructed in a centralized location where the panel workshop is close to the construction site. However, the construction progress by using Risha had hampered by the panel supplier/ applicator who could not meet the schedule. Therefore, development in several different places with only the Risha method was unsuccessful and had to be combined with other methods, for instance, Risba and other earthquake-resistant house methods.

\section{Research Method}

\subsection{Research Area}

The research area is generally in Palu City, Sigi Regency, and Donggala Regency (Figure 1). Temporary shelter locations are spread throughout the research area, and permanent house locations are in Duyu Village and Tondo-Talise Village, Palu City, and Pombewe Village, Sigi Regency.

\subsection{Research Method}

The research uses an evaluation of the temporary shelter development result and a comparison of the permanent house reconstruction approach to other rehabilitation and reconstruction programs in Indonesia, which can indicate the possible outcomes of development and potential problems in Central Sulawesi.

\subsection{Data Collections}

The evaluated temporary shelters are focused on the shelters that were built by the Ministry of Public Works and Housing/ PUPR. The temporary shelter data was achieved by questionnaires, interviews, and field observations. The questionnaire was given to the participants by applying a purposive sampling technique. The total number of participants is 96 people who are the temporary shelter coordinators or the inhabitants since the beginning. The questionnaire questions comprise of the closed questions and open questions. The closed questions were used to identify the level of community satisfaction related to the physical condition of the temporary shelter, the location from the workplace, sense of security, clean water facilities, and access to public facilities. These closed questions are arranged on a 4-level Likert scale, namely agree (value 4), slightly agree (value 3), somewhat disagree (value 2), and disagree (value 1). The method was used to describe the community satisfaction level based on the final value of the total participants.

Meanwhile, other open questions related to the information of expanding the room, the reasons for the refugees who have left the shelters, changes in the community socio-economic life, problems, and criminal incidents that have occurred. These open questions were asked through interviews to scrutinize the real problem in the field. Specific information that was obtained at a location was then asked all participants at the same shelter location. Data from the questionnaire, interviews, and field observations are the source for the temporary shelter development evaluation.

Data collections on permanent house program used interviews, field observations, and rehabilitation and reconstruction documents review. Interviews were conducted with the Central Sulawesi Residential Agency and Local Disaster Management Agency/ BPBD. The Residential Agency explained the relocated house and satellite house programs, while BPBD described the information about the house reconstruction project by using stimulant funds.

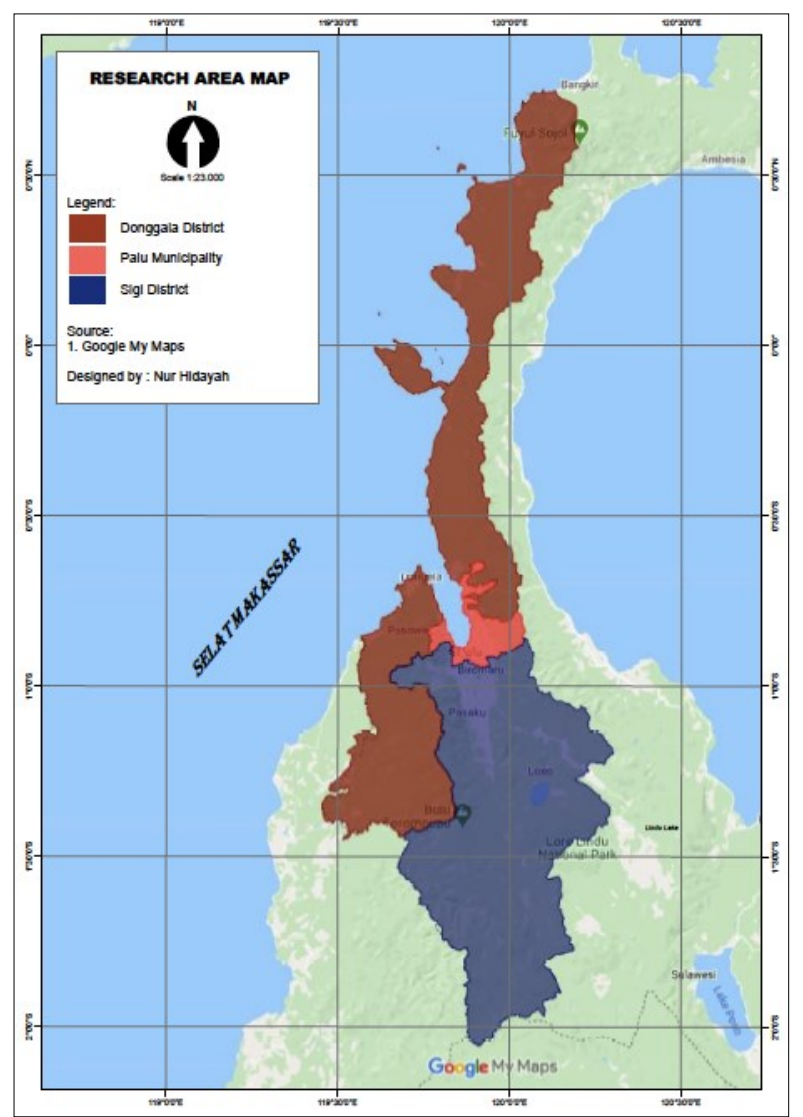

Fig. 1. Research area map 


\section{Results and Discussion}

The analysis report comprises temporary shelter development and utilization, permanent house programs, and the proposed method for rehabilitation and reconstruction of post-disaster settlements in Central Sulawesi, as discussed in this section.

\subsection{Temporary shelter development and utilization}

Following the disaster, the Government had to decide whether to build temporary shelters or directly supply permanent houses. Considering the community activities must be immediately returned to normal conditions, and the liquefaction and tsunami have lost many houses and lands, the Government has decided to build centralized temporary shelters.

The temporary shelter construction was started by land preparation, which was hampered by several problems as below.

1) Many landowners did not lend the lands to the government.

2) Several available lots are forbidden to build since the lots are classified as disaster-prone zones

3) Several other available areas can not be immediately used due to the transferring land status of cultivation right/ HGU, which takes a long time.

4) Locations changes in several areas. To overcome these limitations, the local governments use public lands such as soccer fields and private property with a 2-year land use agreement. There is no payment for private landowners. The shelters also could not be directly constructed by the PUPR. Several locations required land clearing and land development, for instance, cut and fill work in the Petobo Village. This land preparation caused shelter development planning to take a lot of time.

The number of the post-earthquake temporary shelter was adjusted to the number of displaced people who desired to be moved. The number of the needed temporary shelter was initially 1,200 units. However, many refugees had no desire to move to the temporary shelter, and many donor dwellings have been built. As a result, the PUPR only set up 699 units in 72 locations. Each unit has 12 rooms for 12 households [12]. The temporary shelters were assigned to homeless refugees, elders, and families with a baby as the priority. Temporary shelters started to be gradually occupied since December 2018. However, until July 2019, not all rooms were occupied by refugees [13]. It can be seen in Table 1 and Figure 2.

Table 1. Number of temporary shelter occupations

\begin{tabular}{|l|c|c|c|c|}
\hline \multirow{2}{*}{ Location } & \multicolumn{2}{|c|}{ Room (unit) } & \multicolumn{2}{c|}{ Percentage of Occupancy } \\
\cline { 2 - 5 } & Unoccupied & Occupied & Unoccupied & Occupied \\
\hline Palu & 1,709 & 1,747 & $49 \%$ & $51 \%$ \\
\hline Sigi & 1,273 & 1,379 & $48 \%$ & $52 \%$ \\
\hline Donggala & 1,058 & 1,222 & $46 \%$ & $54 \%$ \\
\hline Total & $\mathbf{4 . 0 4 0}$ & $\mathbf{4 . 3 4 8}$ & $\mathbf{4 8 \%}$ & $\mathbf{5 2 \%}$ \\
\hline
\end{tabular}

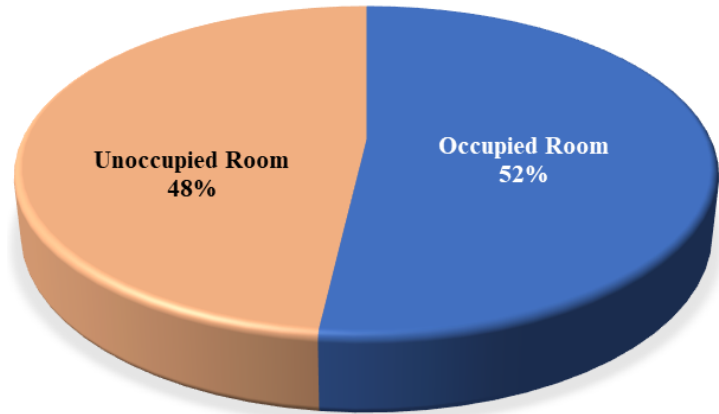

Fig. 2. Percentage of temporary shelter occupation

Many aspects related to the temporary shelter conditions that influence the comfort level of refugees can be seen from the physical quality of the shelters and the quality of the community's social life. First, the physical quality of the shelters is determined by the room capacity, shared room capacity, room lighting and air condition, room privacy, and clean water supply. Second, the quality of community social life is found out by the ability of the community to access several public facilities and workplaces, and the sense of secure living in the temporary shelters. The public facilities are schools, medical services, worship places, markets, and open spaces. The community's ability to access these facilities is influenced by the distance from the temporary shelter and the availability of transportation modes. All components above were asked in the closed questions of the questionnaire.

Generally, the occupants' satisfaction rate of the temporary shelter can be seen in Figure 3. From Figure 3 , the physical shelter conditions are rated less or not comfortable with all components' value below 3 . Components such as room capacity, lighting and air condition, and room privacy are factors that cause the temporary shelter to be uncomfortable for occupants throughout the study area. Regarding lighting and air condition, $100 \%$ of participants gave one point. This lowest score was given because all participants complained about the same thing, which is the hot temperature inside the room during the day. The lack of air circulation due to the opening's limitation in the door and window is unsuitable with hot temperatures in the research area, likewise, room privacy. The thin walls and shared multiplex floors with adjacent rooms create noise or footsteps disturbance and lack of occupant privacy. While related to room capacity, the prototype room is deemed insufficient to accommodate a family of 4-5 people. Space additional in the front of the room is commonly seen in the shelters.

PUPR built the public kitchen, washing room, and bathroom in the shared room for each unit, while the room can only be used for bedroom and living room. However, the occupants felt that the public kitchen capacity was inadequate when all the occupants use it at the same time, unsuitable with the occupants' desires, lack of privacy, and frequent theft occurrence of personal kitchen tools. The kitchen is the most common additional space in each room. Also, additional spaces for terraces, bedrooms, stall of domestic needs in front 


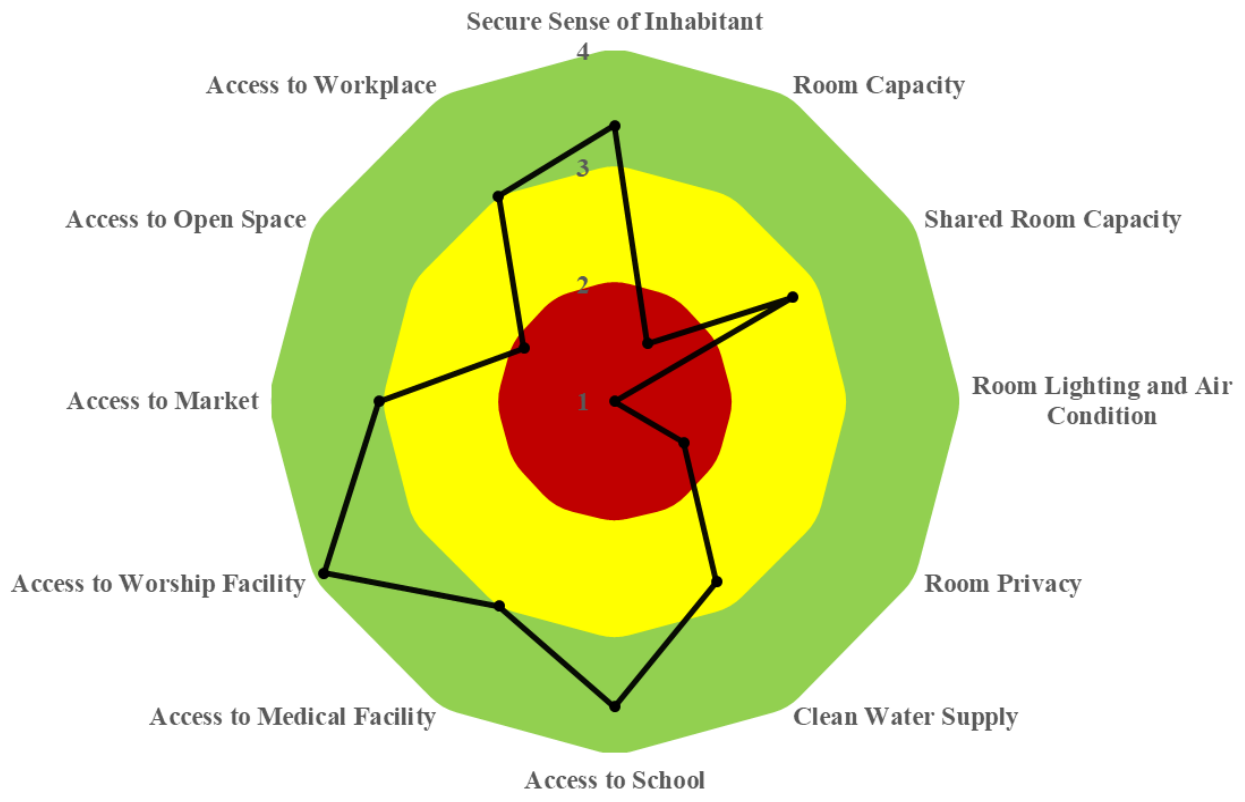

Fig. 3. The satisfaction rate of the temporary shelter

of the room can be seen in almost all units of the temporary shelter.

Regarding the satisfaction rate of the clean water availability, the occupants generally less agree that it is easy to obtain clean water. Water is relatively more comfortable to be accessed in Sigi Regency than in Palu City and Donggala Regency. However, following the disaster, several areas in Sigi Regency experienced drastic water shortages, namely in Pandere Village, Kalawara Village, and Pakuli Village in Gumbasa District. Additionally, the shelter occupants in Ganti Village of Donggala Regency also experienced the same issue. All occupants currently abandon the temporary shelter in Pakuli Village and Ganti Village. These problems above caused many refugees to leave the shelter.

Besides, the satisfaction rate is also determined by social life quality. The social life quality is demonstrated by the access to facilities and workplaces, and the secure sense during living in the shelter. The Government built new public facilities or upgrade existing ones such as schools, medical services, worship places, and markets near the shelters to supply the primary needs of refugees. Although many participants were unable to access open spaces, the occupants slightly agreed and agreed that the distance of the facilities from the shelters was reachable. The security level of shelter inhabitance is acceptable. The low rate of access to open space was due to a lack of its development in the shelter areas. For these reasons and there are no other temporary shelter options, many occupants still inhabit the shelters until the permanent houses construction is finished.

Several facts linked to the satisfaction rate and occupancy rate of the temporary shelter can be seen below.

1) Almost all temporary shelters have uninhabited units unless the units in Bangga Village, Sigi Regency which accommodate refugees of the 2018 earthquake and 2019 flash flood. Other temporary shelters begin to be abandoned based on several issues in each location (Figure 4) such as:

a. In Palu City, the causes are impractical occupants mobilization between the workplace and the temporary shelter and living cost assistance absence during the temporary shelter inhabitancy.

b. In Sigi Regency, the causes are impractical occupants mobilization between workplace and the temporary shelter, living cost assistance absence, uncomfortable temporary shelter conditions, and several occupants return to their reconstructed or reconstruction-on progress houses.

c. In Donggala Regency, the cause is a lack of clean water supply.

2) Small capacity unit caused many households to expand the unit size. The kitchen is the most common additional room since the public kitchen does not fit the privacy needs, and there are many theft cases (Figure 5).

3) $22,92 \%$ of the house is in a light damaged condition, which has been fixed or neglected by the occupants (Figure 6).

4) Some sexual assaults had occurred in Donggala Kodi Village and Petobo Village, Palu City. The crimes were not investigated further.

The earthquake has induced a change in the refugees socio-economic life, particularly in the livelihoods. Living cost assistance from the local governments, which is no longer provided, has led the refugees to return to work, either with the same job in the original workplace or the different jobs. Several unemployed refugees in Duyu shelter even returned to the refugee 
camps for charitable assistance. The refugees who changed their jobs, for instance, fishers and farmers, were affected by the changing of the workplace due to the tidal flood and dry irrigation channels. These people consequently turn to work in the informal sectors. By contrast, several refugees who return to work with the original jobs experienced farther distance to the workplace and higher cost since living in the temporary shelter. For this impracticality reason, many refugees eventually built a temporary house to take care of their fields or fishery products at the workplace or initial house location, which is in the red zone. It made the primary purpose of moving the refugees to a centralized shelter not achieved. The community continues to return to the prohibited area because of economic demands.

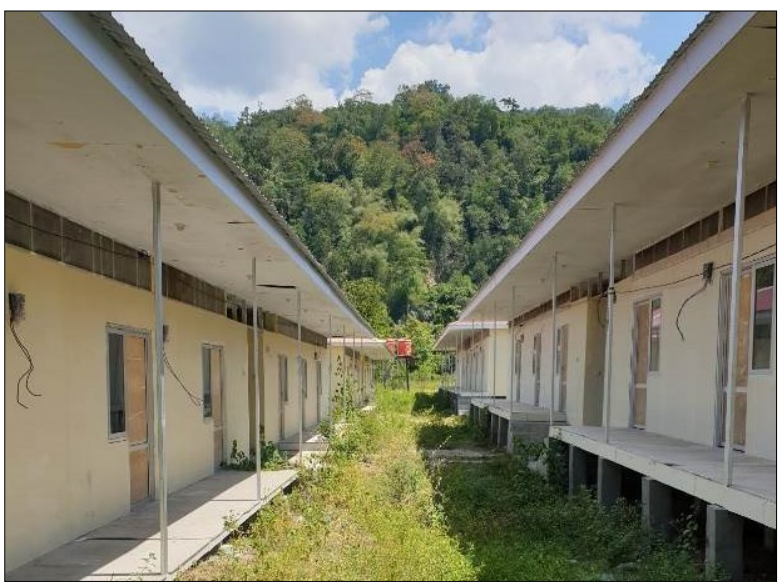

Fig. 4. Fully-unoccupied temporary shelter in Pakuli Village, Sigi Regency

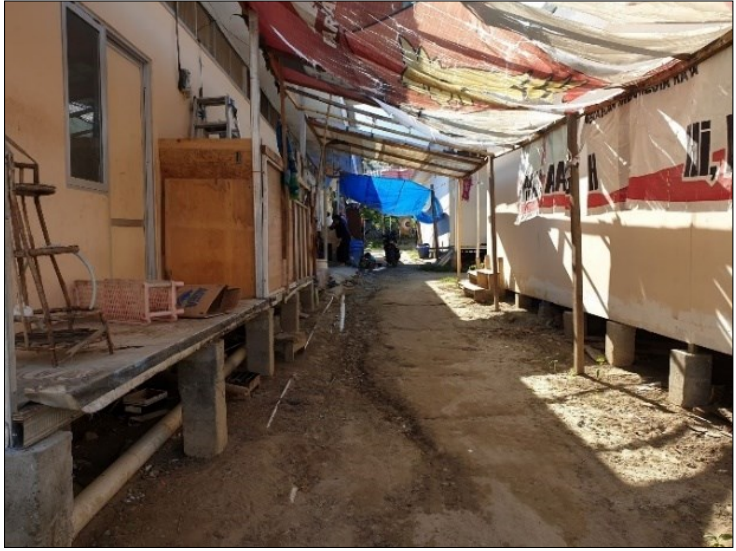

Fig. 5. The additional kitchen at the shelter in Silae Village, Palu City

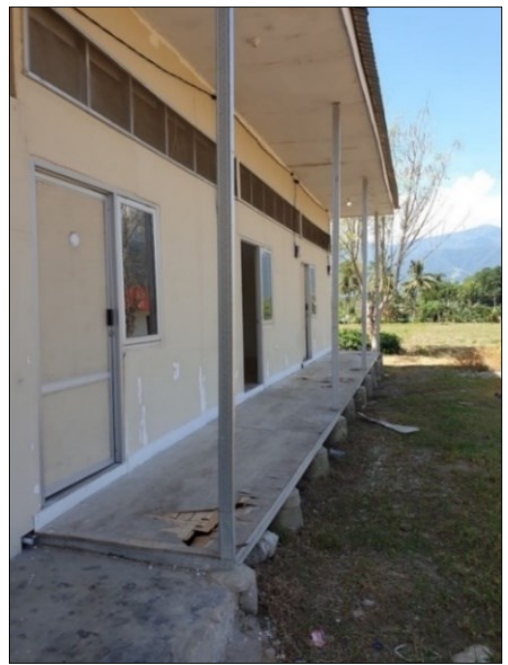

Fig. 6. Floor damaged at the shelter in Kalawara Village, Sigi Regency

Table 2. The indicators of temporary shelter development evaluation in Central Sulawesi

\begin{tabular}{|c|c|c|c|}
\hline No & $\begin{array}{l}\text { Indicator } \\
\text { Categories }\end{array}$ & Indicators & Data Source \\
\hline 1 & Occupancy & $\begin{array}{l}\text { a. House completion rate } \\
\text { b. Household occupancy rate } \\
\text { c. Household satisfaction (of the house, services, and } \\
\text { comfort) }\end{array}$ & $\begin{array}{l}\text { Interview and field } \\
\text { observations }\end{array}$ \\
\hline 2 & Community & $\begin{array}{l}\text { a. Access/ quality of social services } \\
\text { b. Distance to the workplace }\end{array}$ & Field observations \\
\hline 3 & Program & $\begin{array}{l}\text { Cost per construction unit (house and community } \\
\text { facilities) }\end{array}$ & Interview \\
\hline
\end{tabular}

Table 3. Results framework matrix

\begin{tabular}{|c|c|c|}
\hline Project Development Objective & $\begin{array}{l}\text { Project Development } \\
\text { Objective Indicators }\end{array}$ & Use of Outcome Monitoring \\
\hline $\begin{array}{l}\text { The temporary shelter development to } \\
\text { relocate the community from disaster sites } \\
\text { (maximum two years) }\end{array}$ & $100 \%$ shelter occupied & $\begin{array}{l}\text { The indicator shows the effectiveness of the } \\
\text { temporary shelter's development }\end{array}$ \\
\hline Intermediate outcome & Outcome indicators & Use of outcome monitoring \\
\hline $\begin{array}{l}\text { Component 1: } \\
\text { The provision of } 699 \text { units of temporary } \\
\text { shelter and clean water }\end{array}$ & $\begin{array}{l}\text { Shelter completion rate } \\
\text { Household occupancy rate } \\
\text { Household satisfaction }\end{array}$ & $\begin{array}{l}\text { The indicator shows the progress of construction } \\
\text { The indicator shows how effectively the house is } \\
\text { used } \\
\text { The indicator shows the building success or } \\
\text { effectiveness }\end{array}$ \\
\hline $\begin{array}{l}\text { Component 2: } \\
\text { The provision of supporting services and } \\
\text { access to workplace }\end{array}$ & $\begin{array}{l}\text { Easy access to facilities } \\
\text { Access to workplace }\end{array}$ & $\begin{array}{l}\text { The indicator shows the effectiveness of built } \\
\text { facilities } \\
\text { The indicator shows the effectiveness of the } \\
\text { temporary shelter location to the workplace }\end{array}$ \\
\hline
\end{tabular}


The result of temporary shelter development is evaluated using several outcome indicators, as seen in Table 2 [14]. The evaluation indicators are used in the results framework matrix [15], as seen in Table 3.

The temporary shelter is evaluated by using components 1 and 2. From component 1, the shelter development results are obtained through the indicators of shelter completion rate, the occupancy rate, and household satisfaction. The shelter construction was initially scheduled to be completed within three months (October - December 2018) but experienced delay until April 2019. The suspension was caused by the land providing process and insufficient materials. Simultaneous shelter constructions in several locations induced the scarcity of the materials.

Regarding the occupancy rate, with only $52 \%$ of shelters are occupied, it indicates the centralized shelter is not effectively applied in Central Sulawesi. In only seven months (December 2018 - July 2019) since the first shelter was inhabited, low occupancy rate made many shelter units are useless and inefficient. Likewise, household satisfaction with shelter, services, and comfort, which is shown by the low value of the physical shelter condition, exhibits the temporary shelter is unable to afford comfort for the occupants.

Regarding component 2, based on the questionnaire, the ability of facilities and workplace access is stated to be generally easily accessible, except access to open spaces, where not all shelters are equipped with open spaces.

Following the disaster, several NGOs also built individual shelters that were developed on the refugees' lands or other lands near the refugees' original house. The individual shelters' construction speed was faster than the centralized ones. Also, many people chose to reconstruct their houses because it was more comfortable living in their own house. It also caused the refugees to select to not live in centralized temporary shelters.

Generally, the centralized temporary shelter is considered less effective to relocate the refugees from the disaster areas. All refugees are more practically provided with the individual temporary shelter. The shelter for refugees from the non-red zones can be built on the original land, while the shelter for refugees from the red zone can be provided in centralized locations. The centralized temporary shelter is also considered inefficient compared to the total construction cost of 417 billion rupiahs, where the price of each shelter unit is around 500 million rupiahs.

\subsection{Permanent house development}

The program consists of relocated and satellite house/ ex-situ construction and house renovations/ in-situ. The Residential Agency, PUPR, is responsible for building the relocated houses in two centralized locations (Duyu Village, Palu City and Pombewe Village, Sigi Regency) and satellite houses outside the centralized areas. Additionally, the BPBD is responsible for renovating the community houses, which are reconstructed on the initial location using stimulant funds following damage verification of each house. Same as the pre-construction problem of temporary shelter development, land supply for relocated and satellite house development needed a lot of time for land status transferring process and problem solving related to community claims. As a result, the Ministry of Land and Spatial Planning/ National Land Agency handed over the lands to the PUPR on December 23, 2019.

Relocated house programs are constructing in three locations that have been decided by the Central Sulawesi Governor, such as Duyu Village, Palu City (Figure 7), Pombewe Village, Sigi Regency (Figure 8), and TondoTalise Village, Palu City (Figure 9). The Buddhist Tzu Chi Foundation, an NGO donor, has been constructing houses in Tondo-Talise Village and Pombewe Village since July 2019 (Figure 10, Figure 11), by using a conwood house (non-wood construction) which the house is prioritized for the refugees from the red zone. The Residential Agency begins the phase I development of 630 houses (230 units in Duyu Village and 400 units in Pombewe Village) since January 2020 (Figure 12). The house is Risha's house on a land of $150 \mathrm{~m}^{2}$, which the land can accommodate the future house expansion. Regarding the supply of public infrastructure in the relocated houses areas, the project will be held by the Central Sulawesi Settlement Infrastructure Agency. All relocated house projects are targeted to be completed by September 2020, and public infrastructure supply will be completed by October 2020. All permanent houses must adopt earthquake-resistant house methods. Donors can apply Risha or other house models in which PUPR approves the designs.

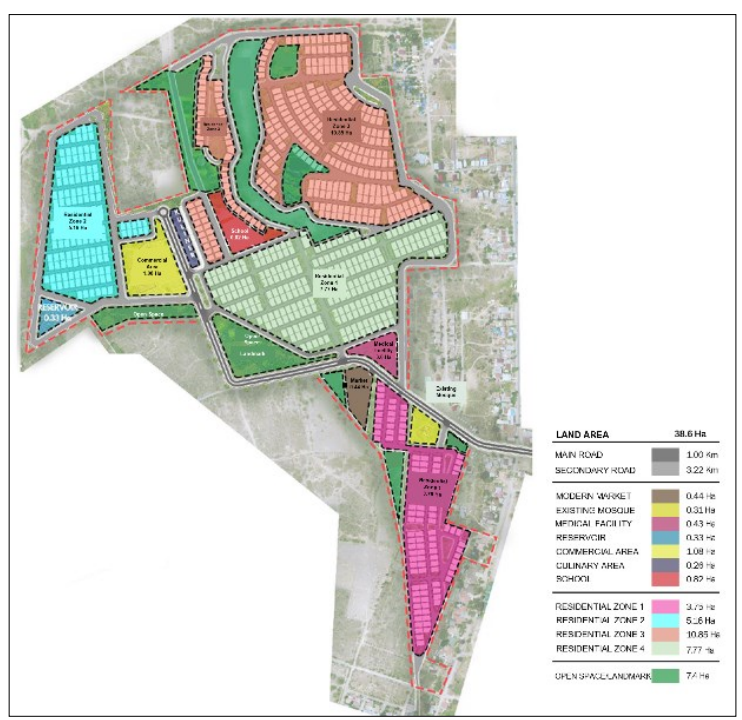

Fig. 7. Relocated permanent houses masterplan in Duyu Village [16] 


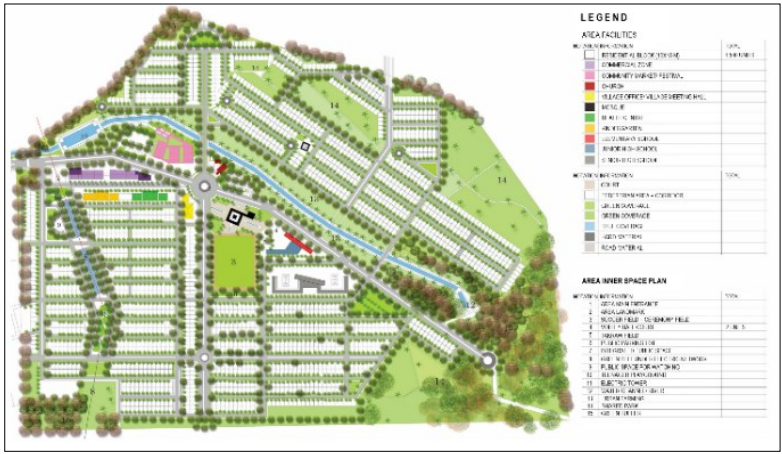

Fig. 8. Relocated permanent houses masterplan in Pombewe Village [16]

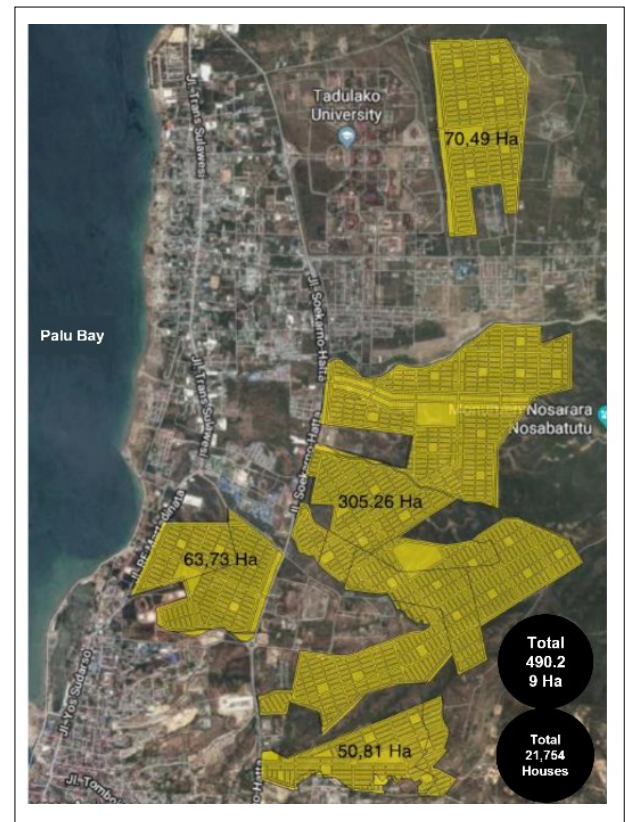

Fig. 9. Relocated permanent houses site plan in Tondo-Talise Village [17]

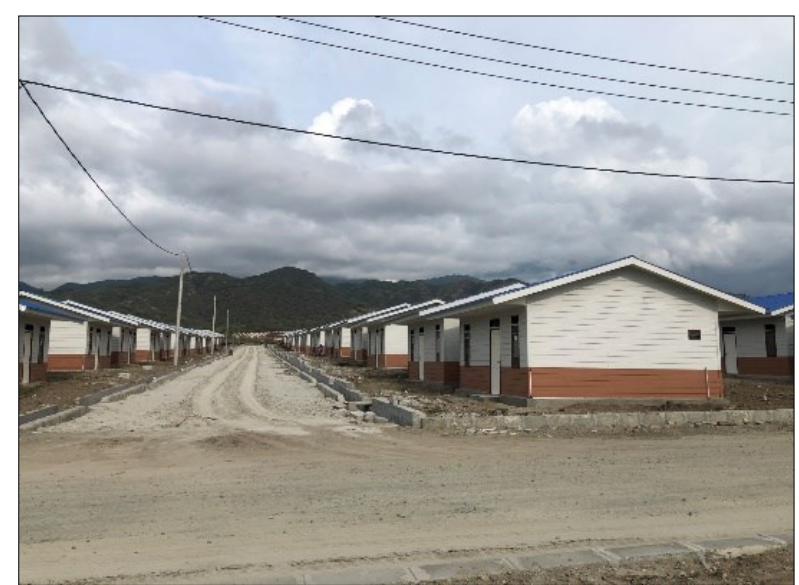

Fig. 10. Permanent house development progress in TondoTalise

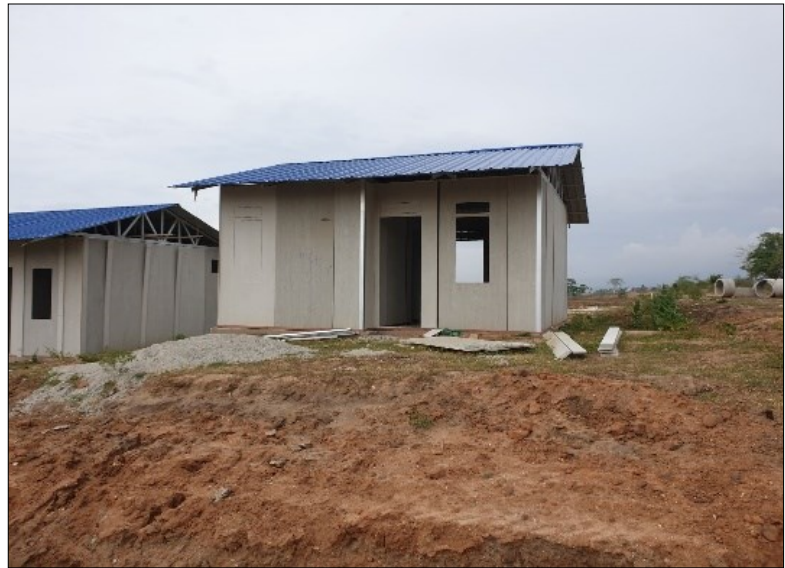

Fig. 11. Permanent house development progress in Pombewe

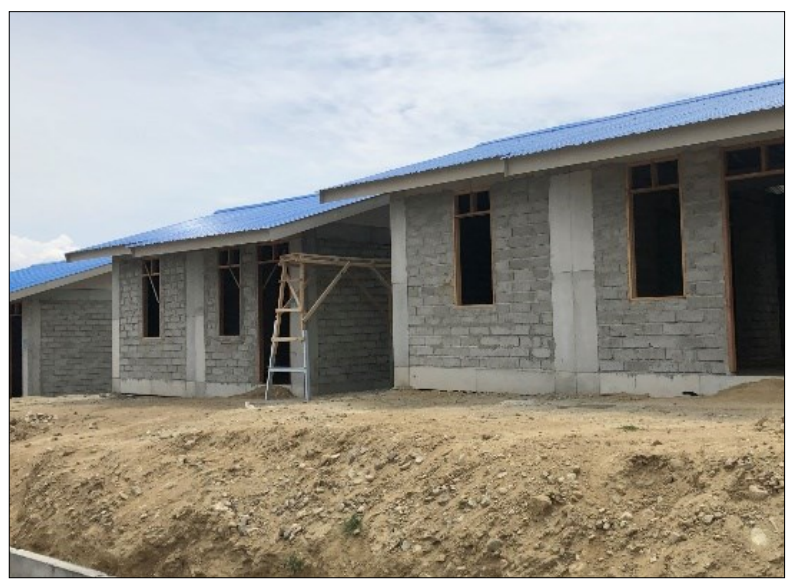

Fig. 12. Permanent house development progress in Duyu

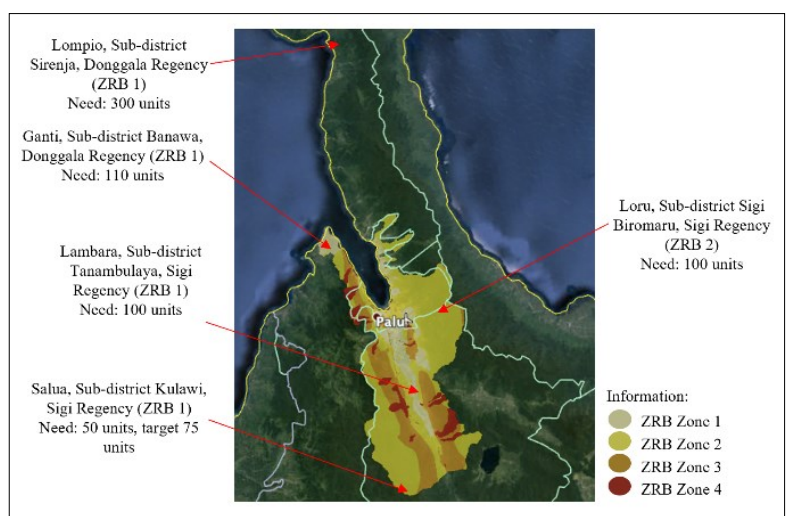

Fig. 13. Satellite house locations [18]

The Residential Agency also must construct satellite houses in Donggala Regency and Sigi Regency (Figure 13). Satellite houses are intended for the community from the red zone, yet the original house location was far from the centralized relocated house location [18].

Satellite houses' development is equipped with access to roads, drainage systems, and clean water resources. Lots of houses, which vary from $96-120 \mathrm{~m}^{2}$, are quite large for a house extension in the future. The house capacity is $36 \mathrm{~m}^{2}$, following the standard of a simple house in Indonesia. The construction begins in August 2020 [18]. 
Satellite house is an alternative to expedite the progress of post-earthquake housing development. The Residential Agency executes the satellite house construction after the first phase of the relocated house construction is completed. It may lengthen the period of stay in temporary shelters in Donggala Regency, and Sigi Regency, especially for those who are far from the location of centralized relocated houses.

Permanent houses are not only built in the relocated sites but also on the initial lands/ in-site. BPBD provides stimulant funds for each house owner of IDR 50 million for the heavily damaged house, IDR 25 million for the moderately damaged house, and IDR 10 million for the light damaged house. The restoration can be constructed on the original land or new one that is outside the red zone. The house reconstruction project is planned for six months. The criteria for stimulant funds receivers as below [19]:

1) Receivers must have legal proof of house ownership;

2) A verified and legalized recipient by the mayor/ regent;

3) If the receiver had more than one house, the subsidy would be given only for one house;

4) Not in the housing support process from other funding sources;

5) If the relatives represent the recipient, the reconstruction fund is only calculated for one house;

6) Own and be able to exhibit the original land ownership document, which is legalized by the local land authority.

In the phase I project in 2019, BPBD only used Risha and conventional house methods. The problems of the phase I project as follow.

1) The project did not immediately run since there were no preparations, facilitators, and implementation guidelines.

2) The reconstruction method must apply the Risha or independent conventional methods. The panel suppliers were not ready with the materials, labors, panel quality required, and capital requirements. It had led many people who had initially chosen Risha to switch to conventional house methods.

3) Many homeowners did not have a fund to demolish the original house and clear the land before the house reconstruction project was started.

4) Several beneficiaries in phase I did not have a house improvement plan. The people still feel comfortable living in a temporary house and as if they do not need house reconstructions. Many people were also waiting for carpenters from other areas or were still working on other housing improvements.

5) Facilitators had to adapt the assistance method to the community rhythm, especially to the local community. Local community characteristics are indifferent, feel normal and comfortable living in a temporary house, and think still have a family in another place, which generated no intention to reconstruct the house immediately. Different characteristics of local people and migrants had caused a long duration of house reconstruction.
The phase II house reconstruction project began in January 2020 with the stimulant funds distribution target for 38,805 houses. House reconstruction projects are erected by using three models, such as fabrication, contractor-built conventional house, and self-supporting conventional house. To avoid the same problems of phase I, BPBD authorizes each stimulant fund recipients to select the preferable house method. Contractors and panel suppliers explain the product advantages to the community. The chosen method is then outlined in the official report for BPBD to provide stimulant funds. Funding disbursement for fabrication and the contractor-built conventional house is transferred through one term $(100 \%)$ after the construction is finalized. Payment for the self-supporting conventional house is split into two terms (a term I by $40 \%$ and term II by $60 \%$ ) [20]. In-site construction by using several method options can raise the level of community satisfaction. During the construction process, the local government technical teams must supervise and ensure the houses have adopted earthquake-resistant house regulations.

This approach is a better way to achieve the house reconstruction completion target while ensuring that the community is responsible for the chosen house method. People must perceive the advantages and disadvantages of each method and learn how to build an earthquakeresistant house. It is expected to boost higher occupancy rates.

From the discussion above, a better rehabilitation and reconstruction method can be proposed. Related to the temporary shelter, the low occupancy rate in the centralized shelters shows several refugees return to the original area, which is the red zone. The low satisfaction rate for indoor airflow, lighting, and privacy, causes the centralized temporary shelter is less effective. Individual shelter, for instance, the Merapi 2010 temporary shelters, with a bathroom and kitchen in each room or not built communally, creates the community more accepts this individual shelter since the shelter provides privacy to occupants as before the disaster. The hot temperature inside the temporary shelter is also a concern in the temporary shelter design improvement by providing additional openings in the room. The individual shelter development also eases donors who intend to supply houses for refugees on the initial land.

Regarding the permanent house programs, the postdisaster settlements reconstruction currently uses three reconstruction approaches, which are as follows.

1) The first approach is an agency-driven reconstruction in relocated site to build relocated houses which are developed by PUPR and donors.

2) The second approach is off-site/modular construction that is used by the relocated house contractors and the community who received the phase I house reconstruction project in 2019.

3) The third approach is an owner-driven reconstruction that is used by BPBD for the phase II house reconstruction project in 2020 .

The agency-driven reconstruction in the relocated site approach and Risha modular construction is 
currently used by PUPR to construct the relocated houses in Duyu Village and Pombewe Village. These approaches do not require a long duration because the entire house design and construction process does not involve the refugees at all. The possible problem is the house incompatibility with socio-cultural conditions and community livelihoods that can generate a low occupancy rate, even though the house is guaranteed for earthquake resistance. Most refugees also choose the relocated house in Tondo Village instead of in Talise Village and Duyu Village. The number of applicants in Tondo Village cannot be entirely accommodated so that it will later be moved to other nearest locations. The displacement of the preferred site will potentially cause the house not to be inhabited.

Risha modular construction has been used as one of the phase I house reconstruction program approach. The program was targeted to reconstruct 1,500 houses for six months (April 26 - October 30, 2019). However, until January 2020, only 500 units have been built. One house method for all beneficiaries should not be used. Panel providers who are may not ready with immense materials needs at the same time are the main concern before setting the use of a house method. To avoid duplicating the phase I progress delay, BPBD set another reconstruction approach for the phase II house reconstruction program.

BPBD implements the owner-driven reconstruction approach for the phase II house reconstruction program. It is applied to ensure each homeowner chooses who will reconstruct the house (by themself, local worker, or contractor) and the house method to be carried out. This approach is the most empowering approach for the community since the homeowner is the house reconstruction program supervisor, and the project can be adapted to the local context and each person's preferences.

The proposed post-disaster permanent house reconstruction method is the owner-driven reconstruction approach for phase II house reconstruction, relocated house, and satellite house projects. The community-driven reconstruction and agency-driven reconstruction approaches are inappropriate for post-disaster recovery in Central Sulawesi. The local people's characters, which are indifferent and feel comfortable in a temporary house, will affect to the community-driven development progress. Several people are likely doing the house project with their desires so that it can slow the progress down. Likewise, the agency-driven reconstruction approach can eliminate the community participation in the house design process, material supply, and experts. The community is only the development spectators. House adjustments or modifications that may be requested by the community can not be communicated, which leads to the low house satisfaction and low occupancy rate. Therefore, the owner-driven reconstruction approach that has been applied in the phase II house reconstruction project needs to be used in the relocated house and satellite house development. The local governments provide centralized sites for the project locations or facilitate developing outside the centralized sites as refugees requested. Development duration will take longer, but the result will be more effective and accepted by the community.

\section{Conclusion}

1) A centralized temporary shelter is less effective in relocating refugees from the red zone and restoring the daily activities of the community. It can be seen from the low occupancy rate that is equal to $52 \%$ and the low satisfaction rate on the shelter condition. Refugees return to their initial house or workplace and build a temporary house for activities as usual.

2) The individual shelter is preferred by refugees rather than communal shelter in a centralized location, in which the individual ones afford more privacy and faster construction duration. Many refugees who were initially allocated a room in the centralized temporary shelter preferred to reconstruct their own houses for privacy and convenience reasons. Individual shelter, for instance, Merapi 2010 shelters, can be considered as an option of successful post-disaster temporary shelter. The individual shelters can be built in a centralized location and inhabited until the permanent house construction is finished.

3) The construction of relocated houses and public infrastructures are still simultaneous ongoing. The development of satellite houses begins in August 2020.

4) Phase II house reconstruction program has a completion target for six months or until the end of 2020.

5) BPBD allows the selecting option of house methods for each beneficiary to accelerate the phase II development progress. The advisory team supervises the community until the house is finished.

6) Land supply for the construction of temporary shelters and permanent houses has become an obstacle that can slow down the pre-construction stage. Land for the permanent house is more challenging to obtain than for the temporary shelters. For instance, the transferring and claims process of the land in Duyu Village and Pombewe Village were completed in December 2019 or 15 months after the disaster.

This paper was part of a Master's research, supported by a scholarship of Ministry of Public Works and Housing, Republic of Indonesia.

\section{References}

[1] United Nations, Sendai Framework for Disaster Risk Reduction 2015-2030. Sendai: United Nations (2015)

[2] The Governor of Central Sulawesi, Governor of Central Sulawesi Regulation No. 10 of 2019 on Post-disaster Rehabilitation and Reconstruction Plans. Palu, Indonesia: Provincial Government of Central Sulawesi 
(2019)

[3] The President of The Republic of Indonesia, Indonesia Presidential Instruction No. 10 of 2018 on Acceleration of Post-Earthquake and Tsunami Rehabilitation and Reconstruction in Central Sulawesi Province and Other Affected Regions. Jakarta, Indonesia (2018)

[4] Indonesia National Disaster Management Authority, Indonesia National Disaster Management Authority Regulation No. 7 of 2008 on Guidelines of Basic Needs Providing Procedures. Jakarta, Indonesia: Indonesia National Disaster Management Authority (2008)

[5] M. Paramita, Merapi Temporary Shelter as Post-disaster Transitional Settlement Recovery. Yogyakarta: Housing Resource Center (2011)

[6] The Governor of Yogyakarta, Governor of Yogyakarta Regulation No. 40.2 of 2010 on The Temporary Shelter Development Guideline. Yogyakarta: Provincial Government of Yogyakarta (2010)

[7] BRR, Housing - Roofing the Pillars of Hope. Banda Aceh: The Executing Agency of Rehabilitation and Reconstruction for Aceh and Nias (BRR NAD-Nias) (2009)

[8] The World Bank, "Rekompak - Rebuilding Indonesia's Communities After Disasters," Jakarta (2012)

[9] M. Kamali and K. Hewage, "Life cycle performance of modular buildings: A critical review," Renew. Sustain. Energy Rev., vol. 62, pp. 1171-1183, (2016) doi: 10.1016/j.rser.2016.05.031.

[10] A. Saputra, Steel Structure Instant House (Risba). Yogyakarta: Gadjah Mada University (2019)

[11] Settlement Research and Development Centre,
Risha (Rumah Instan Sehat Sederhana). Bandung: Ministry of Public Works and Housing (2015)

[12] Central Sulawesi Settlement Infrastructure Agency, "Progress Report of Temporary Shelter Program in Palu, Sigi, and Donggala," Palu, 2019.

[13] Central Sulawesi Settlement Infrastructure Agency, "Basic Infrastructure Condition in the Temporary Shelter Report (July 2019)," Palu, 2019.

[14] A. K. Jha, J. D. Barenstein, P. M. Phelps, D. Pittet, and S. Sena, Safer Homes, Stronger Communities: A Handbook for Reconstructing after Natural Disasters. Washington D.C: The World Bank (2010)

[15] D. Roberts and N. Khattri, Designing A Results Framework for Achieving Results: A How-to Guide. Washington D.C: World Bank Group (2012)

[16] Jakarta Metropolitan Settlement Infrastructure Agency, "Permanent House Masterplan/ Postearthquake Central Sulawesi Relocation," Palu (2019)

[17] Regional Infrastructure Development Agency, Post-earthquake Settlement Siteplan - Tondo Talise, Duyu, and Pombewe. Jakarta (2019)

[18] Residential Agency, "Pre-Construction Meeting of Central Sulawesi Post-disaster Permanent House Program," Palu (2020)

[19] Palu Mayor, Palu City Post-disaster Rehabilitation and Reconstruction Plan 2019. 2020. Palu: Government of Palu City (2019)

[20] Local Disaster Management Agency of Palu, "Technical Instructions of Palu Post-earthquake Settlement Rehabilitation and Reconstruction," Palu (2019) 